\title{
Intrafloral phenology of Trifolium polymorphum Poir. (Leguminosae) aerial flowers and reproductive implications
}

\author{
Gabriela Speroni $^{1,4}$, Primavera Izaguirre $^{1}$, Gabriel Bernardello ${ }^{2}$ and Jorge Franco ${ }^{3}$
}

Received: April 14, 2008. Accepted: March 5, 2009

\begin{abstract}
RESUMO - (Fenologia intrafloral das flores aéreas de Trifolium polymorphum Poir. (Leguminosae) e suas implicações reprodutivas). Trifolium polymorphum é uma espécie que cresce no Uruguai, Argentina, Brasil, Paraguai e Chile. As flores subterrâneas são cleistógamas, autógamas obrigatórias e altamente modificadas na sua estrutura e funcionalidade. As flores aéreas são casmógamas e foram descritas como alógamas e autógamas. Este trabalho tem como objetivo identificar as características florais que facilitam ou evitam os processos de autogamia ou alogamia. A fenologia floral foi correlacionada com os modelos estimados do desenvolvimento das flores aéreas, a viabilidade do pólen e a receptividade estigmática, em três populações uruguaias de T. polymorphum. As variáveis analisadas foram: longevidade e desenvolvimento da flor (comprimento, largura e distância entre anteras e estigma); momento de início da antese e deiscência das anteras; viabilidade do pólen e receptividade estigmática. As flores aéreas têm características que facilitam processos de autogamia ainda em pré-antese e outras características fenológicas que os evitam. Os eventos reprodutivos importantes que ocorrem durante o desenvolvimento da flor e facilitam processos de autogamia ou alogamia são discutidos neste trabalho.
\end{abstract}

Palavras-chave: biologia floral, fenologia intrafloral, sistema reprodutivo, Trifolium polymorphum

ABSTRACT - (Intrafloral phenology of Trifolium polymorphum Poir. (Leguminosae) aerial flowers and reproductive implications). Trifolium polymorphum is an amphicarpic species that grows in Uruguay, Argentina, Brazil, Paraguay and Chile. Underground flowers are cleistogamous, obligately autogamous and morphologically highly modified in structure and function. Aerial flowers are chasmogamous, and as mentioned in earlier literature, either allogamous or autogamous. The aim of this study is to identify flower characteristics that facilitate or prevent autogamous or allogamous processes. Floral phenology stages are thus studied in correlation with estimated models of aerial flower development, pollen viability and stigmatic receptivity in three Uruguayan T. polymorphum populations. Flower longevity and development (length, width, and anther-stigma distance), anthesis and anther dehiscence initiation, pollen viability and stigmatic receptivity are the variables correlated with floral phenology. Morphological characteristics of aerial flowers favor autogamy processes - even in pre-anthesis but phenological characteristics tend to prevent it. The most important reproductive events occurring during flower development, that facilitate autogamous or allogamous processes, are discussed here.

Key words: breeding system, floral biology, intrafloral phenology, Trifolium polymorphum

\section{Introduction}

Trifolium polymorphum (Leguminosae) is a perennial, stoloniferous winter species (Izaguirre 1995) that grows in Uruguay, the virgin Pampa steppe of the Argentine provinces of Buenos Aires, Entre Ríos, Córdoba, Chaco, Santa Fe (Burkart 1987), Corrientes, La Pampa, Río Negro and Misiones in Argentina (Rossow 1999), in the state of Rio Grande do Sul in Brazil, and in Paraguay and Central Chile (Burkart 1987). This amphicarpic legume combines different types of reproductive strategies that make it an interesting subject of study. It has asexual propagation by stolons and sexual reproduction by two kinds of flowers: underground and aerial. Underground flowers are produced during the winter, and are cleistogamous and morphologically highly modified in relation to aerial flowers (Speroni 2000; Speroni \& Izaguirre 2001; 2003). Aerial flowers are produced during spring and show the typical papilionaceous structure; they are reportedly allogamous (Coll \& Zarza 1992), although there are no experimental data to support this assumption. On the other hand, Real et al. (2007) determined that: "the proposed classification for the breeding system of $T$. polymorphum is an allogamous, selfcompatible species that benefits from pollinators to set seed".
One of the main topics in floral biology is to compare self-fertilization with cross-fertilization but self-pollination is not a unique process. It can occur in different ways and at different frequencies in self-compatible species, and can be affected by interpopulation or environmental factors as well (Lloyd \& Schoen 1992). These last authors recognized three ways of autonomous self-pollination: 1) Prior selfing occurs when anthers dehisce and stigmas are receptive before anthesis and the two pollinating surfaces are positioned and oriented so there is contact between them in unopened buds; 2) Competing selfing resembles facilitated selfing in that it occurs during the same interval as crosspollination, but it differs in being achieved autonomously; 3) Delayed selfing occurs when the movements of flower parts at the end of anthesis lead to pollen-stigma contacts and the fertilization of ovules that have not been previously cross-fertilized. Experimental design is required to evaluate and establish the possibilities of one or other method of reproduction in order to determine these characters at the flower level. Quantitative analysis of intrafloral biology previous to reproductive biology studies (especially pollen viability and stigmatic receptivity) contributes to confirming the results obtained in manual pollination treatments, molecular studies and experimental observations. This type of analysis is generally absent in breeding system or seed

\footnotetext{
Universidad de la República, Facultad de Agronomía, Departamento de Biología Vegetal, Montevideo, Uruguay

2 Universidad Nacional de Córdoba, Facultad de Ciencias Exactas, Físicas y Naturales, Córdoba, Argentina

3 Universidad de la República, Facultad de Agronomía, Departamento de Biometría, Montevideo, Uruguay

4 Corresponding author: speronig@fagro.edu.uy
} 
production published works, which can lead to erroneous interpretation of results (Stone et al. 1995). Thus, in order to carry out future manual pollination in T. polymorphum and to confirm the breeding system of the aerial flowers, it is necessary to previously analyze pollen viability and stigmatic receptivity. The main aim of this work consists of correlating intrafloral phenology stages with estimated models of floral development, pollen viability and stigmatic receptivity for this legume species.

\section{Materials and methods}

For this study, Trifolium polymorphum plants from three different populations (Dpto. Florida, 3409'52.6'S; 5552'51.8'W; Dpto.

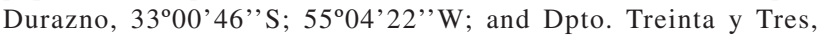
$33^{\circ} 10^{\prime} 38^{\prime \prime}$; $54^{\circ} 24^{\prime} 66^{\prime \prime} \mathrm{W}$ ) were obtained. They were extracted from their local habitat in areas where they were abundant together with the accompanying vegetation in the shape of soil bricks that included all the vegetation as well as the upper $10 \mathrm{~cm}$ of soil. Each superficial soil brick measured 50-60×40-50 cm. For each of the three experimental populations maintained in cultivation in Montevideo (Facultad de Agronomía), 100 young aerial flowers were marked at a stage diagnosed by the corolla completely covered by the calyx (stage 0 ), of 2.0-2.5 mm long. Five different flowers in each population were drawn out daily to record morphological changes, pollen viability and stigmatic receptivity. Flower length (from calyx base to corolla apex), flower width and distance between stigma and anther level were measured (Fig. 1). Changes in the morphological variables were modelled with a nonlinear segmented model, which considers the forms of growth at different stages and predicts the moments of change throughout the sampling period. Flower development curves were modelled in relation to the length, width and distances between stigma and anther level using segmented models (Draper \& Smith 1981). Throughout the sampling period, the beginning of anthesis, dehiscence of anthers, and floral longevity were accurately determined. Flower longevity or anthesis period was considered from the flower opening until the senescence symptoms. These symptoms were regarded as significant when the senescent flowers appeared in 50\% or more of the total daily sample.

Pollen viability was measured by fluorochromatic reaction (FCR), using fluorescein diacetate (FDA) as fluorochrome (Heslop-Harrison 1970 in Shivanna \& Rangaswamy 1992). Sample average percentage curves of viable pollen grains were estimated for each population, and the changes throughout the sampling period were modelled with a second order polynomial model (Draper \& Smith 1981). The pollen viability expected curve for T. polymorphum was estimated.

Stigmatic receptivity was determined daily using á-naphthyl acetate (Pears 1972 in Dafni 1992). Stained stigmas were drawn using a camera lucida attachment to a stereoscopic microscope Wild M5-64793, to estimate the percentage of stigmatic receptivity area. This was calculated using Scion Image 4.02 Beta Win program (for Windows 95 to XP available at http://www.scioncorp.com//frames/ fr_scion_products.htm). The percentage curves of stigmatic receptivity area for each population were estimated, and the changes throughout sampling period were modelled with a second order polynomial model (Draper \& Smith 1981).

\section{Results}

Anthesis started on day six of the sampling period in the three populations, when the vexilar petal was open and the wings and keel petals were exposed. Flowers remained open, without senescence symptoms or with low senescence values $(<20 \%)$ until the sixth day after anthesis onset in population 1 and until the fifth day after anthesis onset in populations 2 and 3 (Tab. 1). A day later, senescence values increased considerably $(>60 \%)$ in all three populations. Anthesis lasted six days in population 1 and five days in populations 2 and 3. Anther dehiscence began during preanthesis. Low dehiscence values (in up to $20 \%$ of sampled flowers) were recorded two days before anthesis in population 1 , three days before anthesis in population 2 , and one day before anthesis in population 3 (Tab. 2). A day before anthesis, a high percentage of dehiscence was observed in populations 1 and $2(>60 \%)$, although maximum percentage was reached at anthesis onset for the three populations. Although anthers were considered in a dehiscent state when they showed a longitudinal slit by the stomium, pollen tubes were observed crossing the anther wall and growing toward the stigma in anthers of three very young, non-dehiscent flowers (Tab. 2).
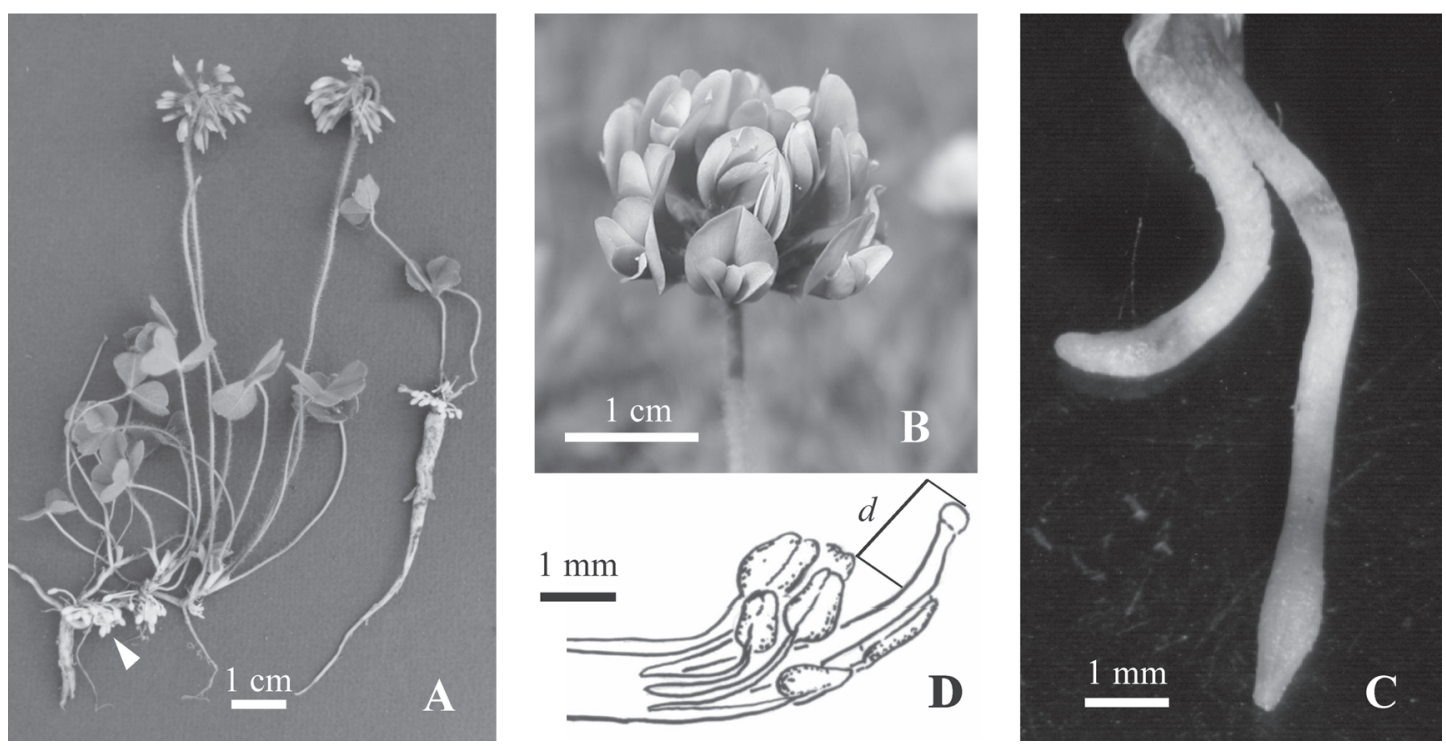

Figure 1. Trifolium polymorphum Poir. A. Plant with aerial and underground (arrow) flowers. B. Aerial inflorescence. C. Two underground flowers. D. Distance (d) measured between stigma and anthers level of aerial flowers. 
Table 1. Trifolium polymorphum Poir. flower senescence $(\%)$ after anthesis onset (day 1) for three populations. Five flowers were sampled each day.

\begin{tabular}{crrrrrrrr}
\hline & \multicolumn{7}{c}{ Days } \\
\cline { 2 - 8 } Population & 2 & 3 & 4 & 5 & 6 & 7 & 8 & 9 \\
\hline 1 & 40 & 20 & 0 & 0 & 20 & 60 & 60 & 100 \\
2 & 20 & 0 & 20 & 20 & 60 & 80 & 100 & 100 \\
3 & 0 & 20 & 20 & 0 & 60 & 100 & 100 & 100 \\
\hline
\end{tabular}

Table 2. Pre-anthesis anther dehiscence (\%) observed during sampling period for three populations of Trifolium polymorphum Poir. Five flowers were sampled each day. (*, samples where pollen grain germination was observed previous to anther dehiscence).

\begin{tabular}{ccccccr}
\hline & \multicolumn{6}{c}{ Days } \\
\cline { 2 - 7 } Population & 1 & 2 & 3 & 4 & 5 & 6 \\
\hline 1 & 0 & $0^{*}$ & $20^{*}$ & 20 & 60 & 100 \\
2 & 0 & 0 & $20^{*}$ & 80 & 80 & 100 \\
3 & 0 & 0 & 0 & 20 & 20 & 100 \\
\hline
\end{tabular}

During floral development in the three populations, aerial flower length grew linearly and then stabilized (Fig. 2). Flowers in populations 2 and 3 reached maximum development at anthesis onset, however flowers of population 1 reached it three days later. Then, flower length remained constant in the three populations, even though senescence symptoms in the floral whorls were confirmed. In populations $2\left(\mathrm{r}^{2}=92.8 \% ; \mathrm{F}=77.1 ; \mathrm{p}<0.0001\right)$ and 3 $\left(r^{2}=93.2 \% ; \mathrm{F}=82.3 ; \mathrm{p}<0.0001\right)$, maximum development was 6.54 and $7.19 \mathrm{~mm}$ respectively, and was reached when anthesis started. In population $1\left(\mathrm{r}^{2}=95.5 \% ; \mathrm{F}=128\right.$; $\mathrm{p}<0.0001$ ) maximum development was $7.74 \mathrm{~mm}$ three days after anthesis onset.

Aerial flower width increased exponentially during floral development, later its growth stabilized, and finally decreased linearly in the three populations (Fig. 3). In the three populations, maximum development was reached two days after anthesis onset. In population $1\left(\mathrm{r}^{2}=99 \%\right.$; $\mathrm{F}=204.9 ; \mathrm{p}<0.0001)$ maximum width development reached $2.88 \mathrm{~mm}$, in population $2\left(\mathrm{r}^{2}=99.2 \% ; \mathrm{F}=242.5 ; \mathrm{p}<0.0001\right)$, $2.56 \mathrm{~mm}$, and in population $3\left(\mathrm{r}^{2}=98.5 \%\right.$; $\mathrm{F}=129.8$; $\mathrm{p}<0.0001), 2.89 \mathrm{~mm}$. The flowers remained open during the night, although the vexilar petal could display slight movements of opening and closing during anthesis period. The linear decrease in flower width began close to five days after anthesis onset in the three populations.

During flower development, the androecium and gynoecium had differential growth that caused the approaching or the spacing between anthers and stigma (Fig. 1). Both whorls were in close proximity in young flowers, though later the gynoecium had a greater extension rate and surpassed the height of anther level. Subsequently, stamen filaments extended and the anthers approached the stigma once again. The distance between these two whorls had a quadratic development (Fig. 4), reaching maximum separation two days before anthesis onset and the gratest approach one day after anthesis onset in the three populations. Later, the distance between the two whorls

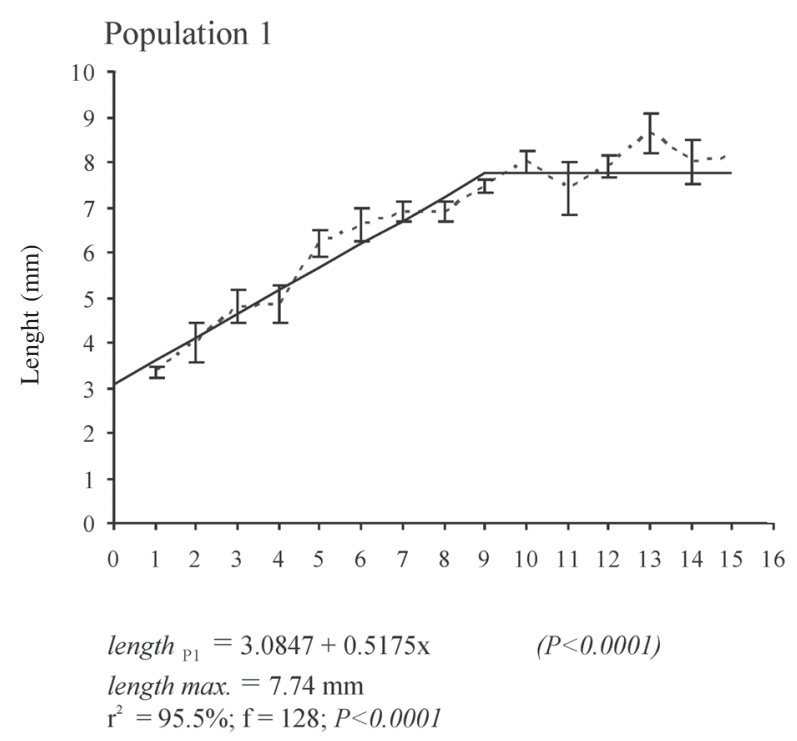

Population 2

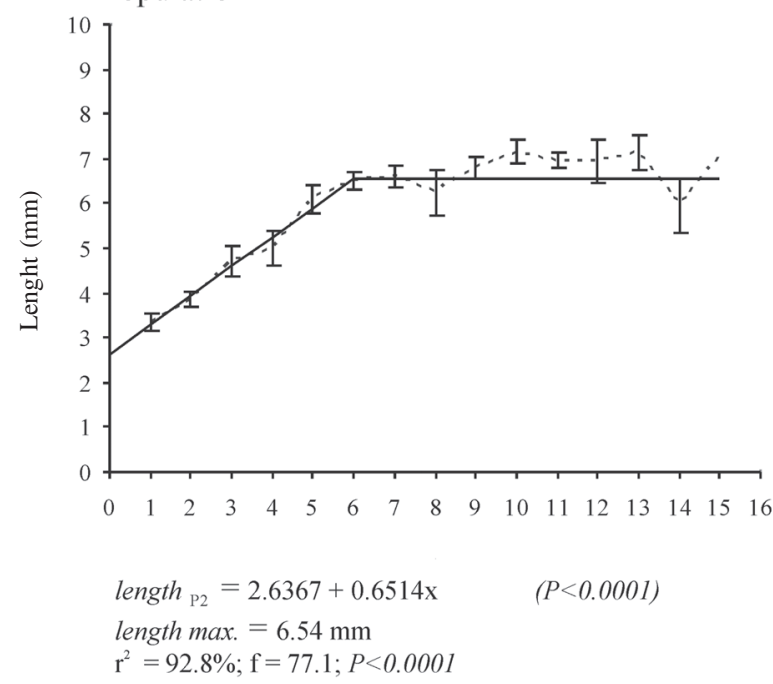

Population 3

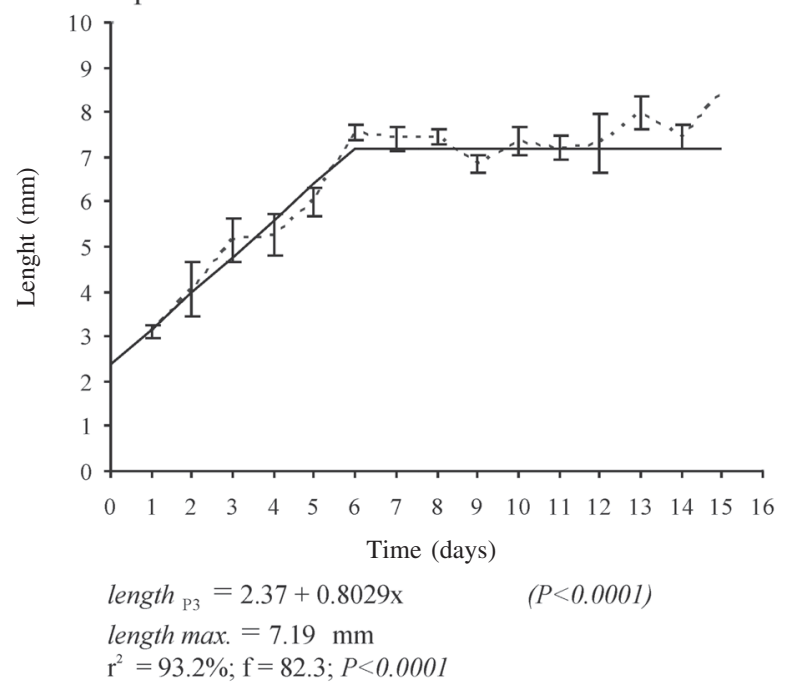

Figure 2. Trifolium polymorphum Poir. flower length. Observed average values (---) and segmented model (-) linear-linear for the three populations. 


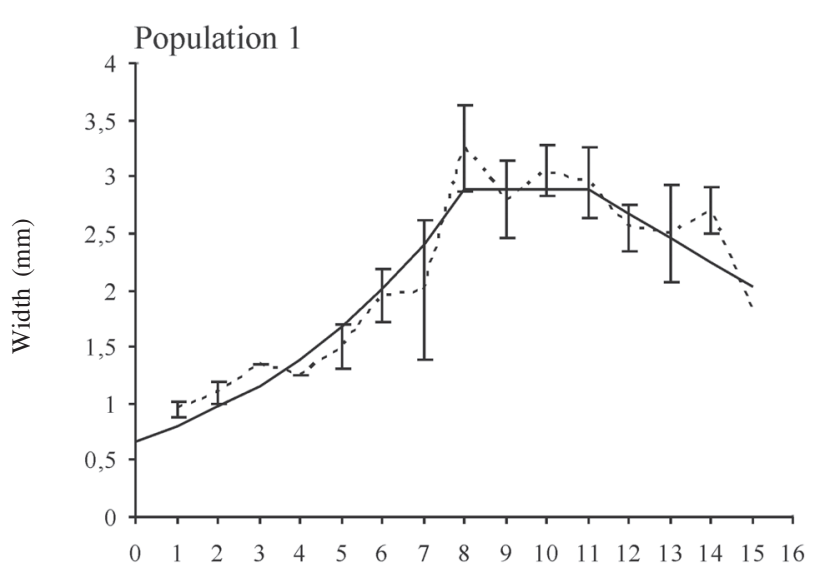

$$
\begin{array}{ll}
\text { width }_{1-7 \text { days }}=\mathrm{e}^{(-0.3968+0.1818 \mathrm{x})} & (P<0.0001) \\
\text { width max. }{ }_{8-11 \text { days }}=2.879452 \mathrm{~mm} & (P<0.0001) \\
\text { width }_{11-1 \text { sdays }}=2.8794520 .214(\mathrm{x} 11) & (P<0.0001) \\
\mathrm{r}^{2}=99 \% ; \mathrm{f}=204.9 ; P<0.0001 &
\end{array}
$$

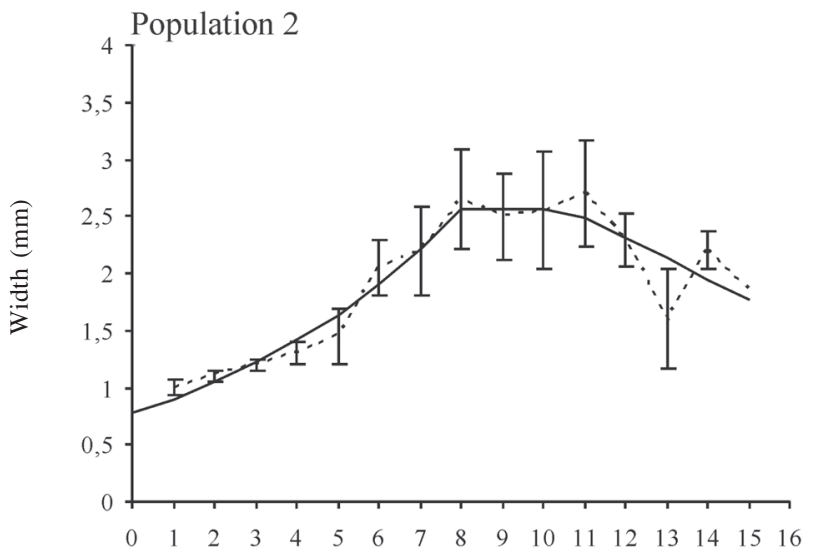

$$
\begin{aligned}
& \text { width }_{1-7 \mathrm{days}}=\mathrm{e}^{(-0.2527+0.1491 \mathrm{x})} \quad(P<0.0001) \\
& \text { width max. }{ }_{8-10.6171 \text { days }}=2.560237 \mathrm{~mm} \quad(P<0.0001) \\
& \text { width }_{10.6171-1 \text { days }}=2.5602370 .180(\mathrm{x} 10.6171)
\end{aligned}
$$$$
\mathrm{r}^{2}=99.2 \% ; \mathrm{f}=242.5 ; P<0.0001
$$

Population 3

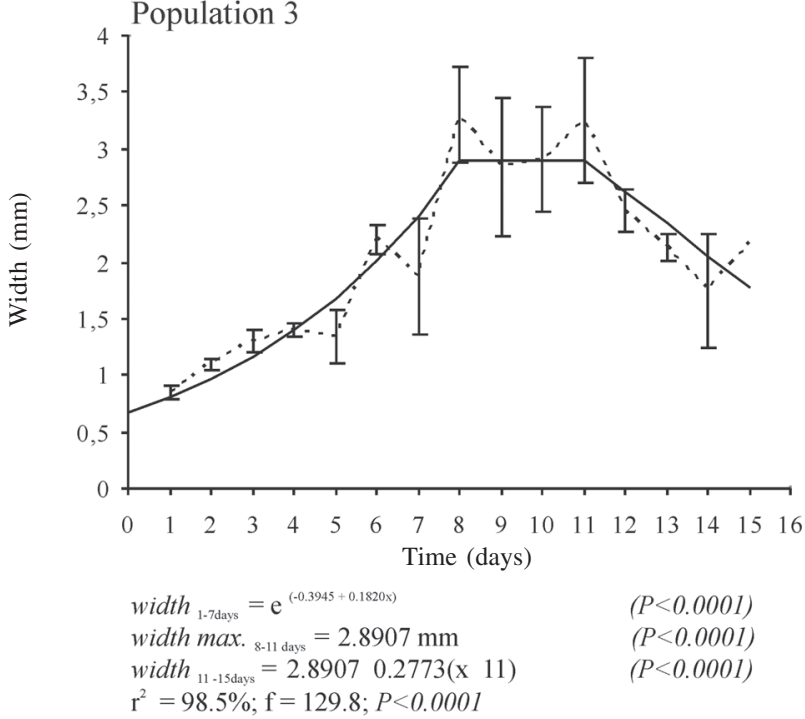

Figure 3. Trifolium polymorphum Poir. flower width. Observed average values (---) and segmented model (-) exponential-linear-linear for the three populations.
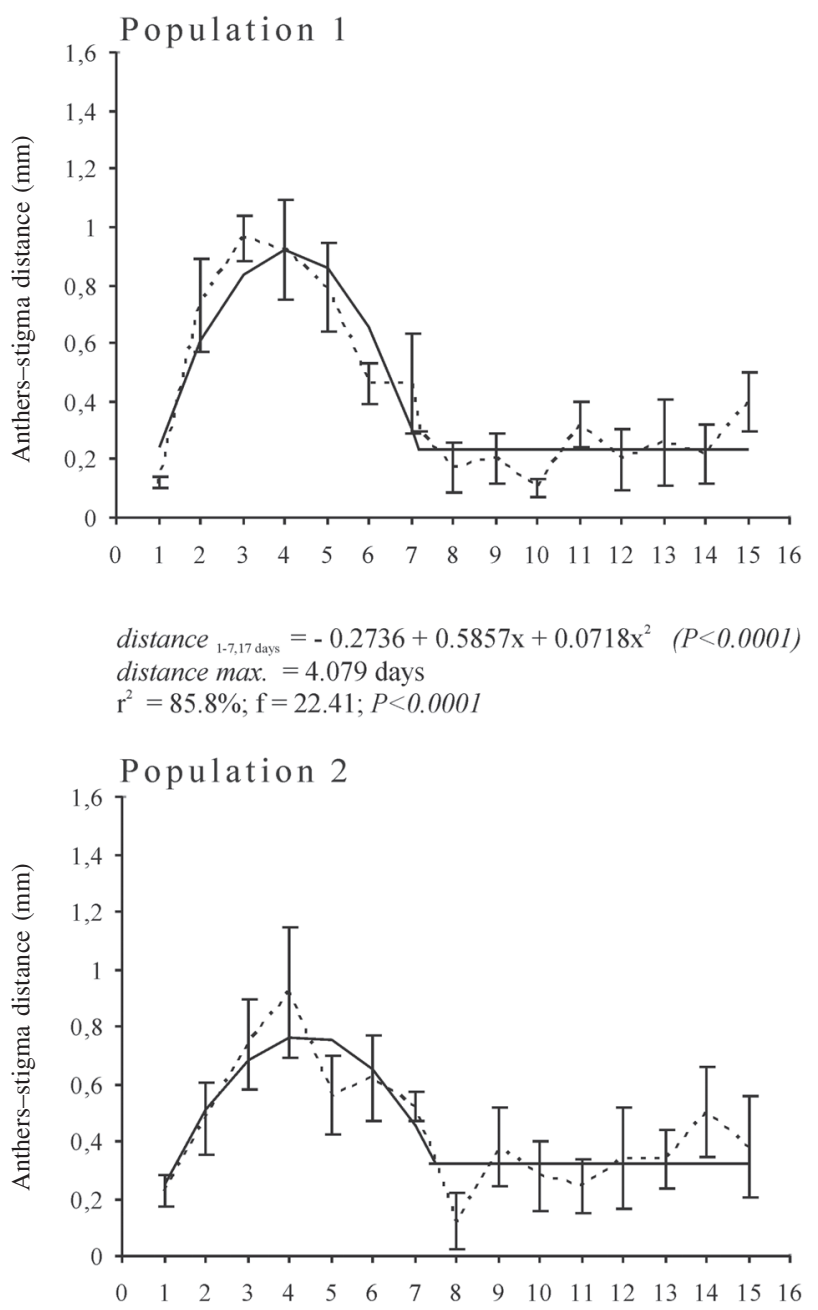

distance $_{1-7.52 \text { days }}=-0.10+0.3975 \mathrm{x}+0.0454 \mathrm{x}^{2} \quad(P<0.0015)$ distance $\max .=4.3778$ days

$\mathrm{r}^{2}=74.2 \% ; \mathrm{f}=10.53 ; P<0.0015$

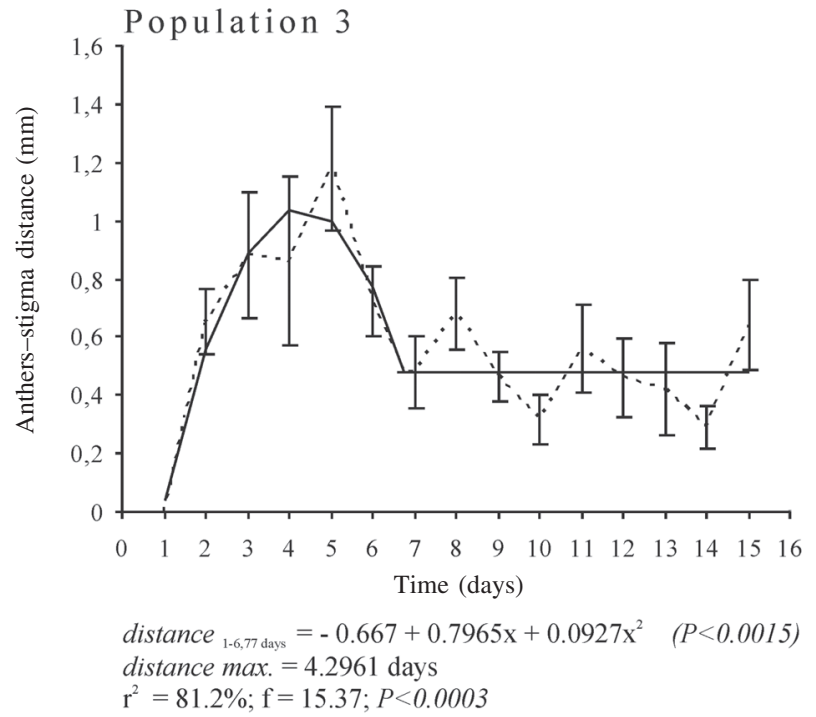

Figure 4. Trifolium polymorphum Poir. anthers-stigma distance. Observed average values (----) and segmented model (-) quadratic-linear for the three populations. 
remained constant. The greatest spacing was $0.92 \mathrm{~mm}$ $\left(r^{2}=85.8 \% ; F=22.41 ; p<0.0001\right), 0.76 \mathrm{~mm}\left(r^{2}=74.2 \%\right.$; $\mathrm{F}=10.53 ; \mathrm{p}<0.00015)$, and $1.03 \mathrm{~mm}\left(\mathrm{r}^{2}=81.2 \% ; \mathrm{F}=15.37\right.$; $\mathrm{p}<0.0003$ ) in population 1, 2 and 3, respectively. A day before anthesis, filaments began to extend, reaching their greatest approach to stigma one day after anthesis. When the distance between the two whorls remained constant, the anthers were slightly beneath the stigma (near 0.23 $-0.48 \mathrm{~mm})$.

Pollen viability showed great variability in the daily values measured for the three populations, as indicated by standard error (Fig. 5). Pollen viability increased during preanthesis and reached maximum values (around 60\%) between one and two days after anthesis onset, for the three populations $\left(\mathrm{r}^{2}=56.8 \% ; \mathrm{F}=99.9 ; \mathrm{p}<0.0001\right)$. Nevertheless, very high values (up to more than $80 \%$ ) were recorded before anthesis in some flowers of the three populations.

The gynoecium presented an apical, slightly capitate stigma. This last morphological characteristic became more evident near the third day of sampling (Fig. 1). During flower development, an expanded apical zone was clearly observed on the stigma, where stigmatic papillae were observed in anatomical sections. This papillate region coincides with the receptive zone detected with á-naphtyl acetate. Receptive regions in the stigma were registered at early stages of floral development during pre-anthesis (Fig. 6). Daily registered values presented great variability, as is shown in Fig. 6. The stigmatic receptivity increased during pre-anthesis and reached maximum values (65-76\%) between three and four days after anthesis onset in the three populations $\left(r^{2}=46 \% ; F=172.01 ; p<0.0001\right)$. Later, stigmatic receptivity decreased.

\section{Discussion}

Intrafloral phenology studies contribute to the knowledge of plant reproductive biology, considering not only the period in which the flower remains open (anthesis period or floral longevity) but also pre-anthesis events. Both can influence species reproduction, thus providing basic data for planning experimental work. Some morphological and phenological flower characteristics can facilitate or hinder spontaneous self-pollination in allogamous species (Lloyd \& Schoen 1992), even at previous or later stages of floral longevity. Statistical analyses and quantification data in intrafloral phenology studies, as synthesized in Fig. 7, are important tools to determine the exact timing of manual pollinations and to improve interpretation of molecular approaches to conclusively confirm the breeding system of T. polymorphum. Here we showed models for this species for the parameters length, width, anther-stigma distance, pollen viability and stigmatic receptivity, which indicated significant events in flower life such as the beginning of anthesis, the beginning of anther dehiscence, and the beginning of floral senescence.
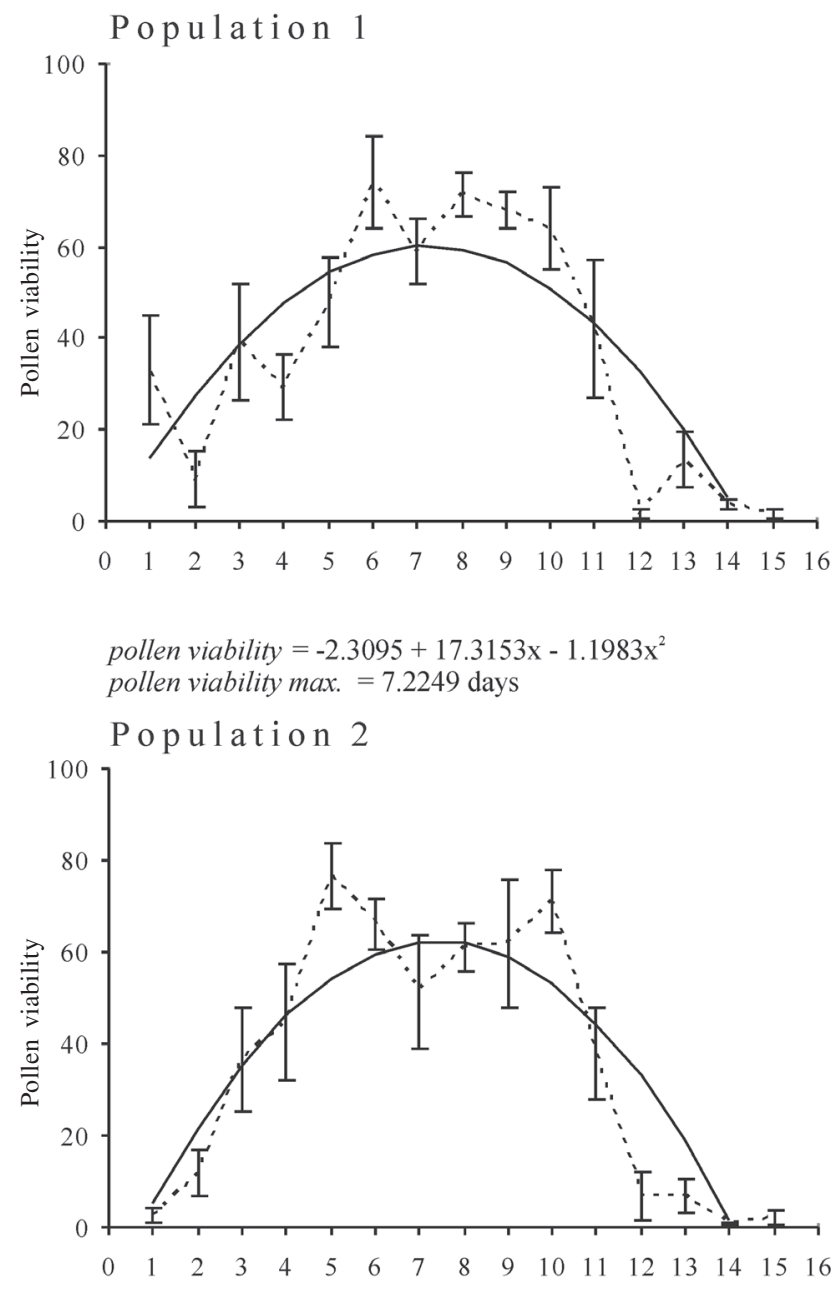

pollen viability $=-14.0848+20.6779 \mathrm{x}-1.3962 \mathrm{x}^{2}$

pollen viability $\max .=7.4051$ days

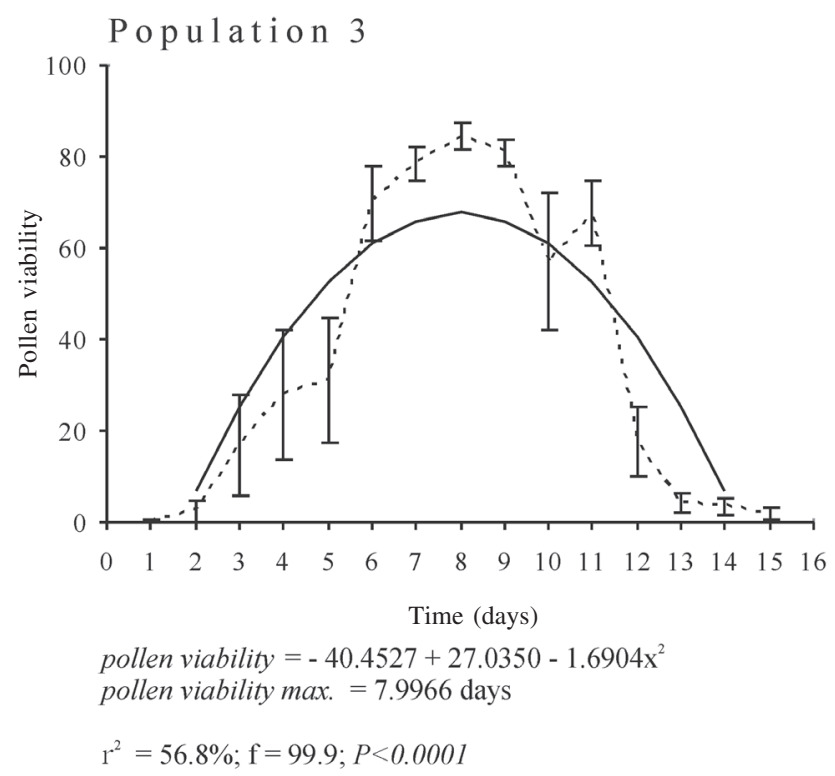

Figure 5. Trifolium polymorphum Poir. pollen viability. Observed average values (---) and second order polinomial model (-) for the three populations. 


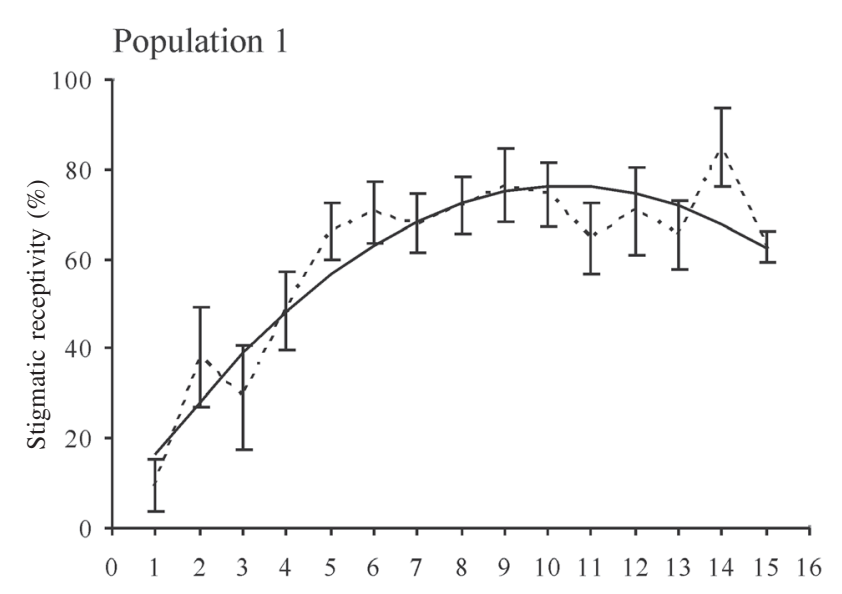

stigmatic receptivity $=2.8574+14.0708 \mathrm{x} 0.6741 \mathrm{x}^{2}$ stigmatic receptivity $\max .=10.4367$ days

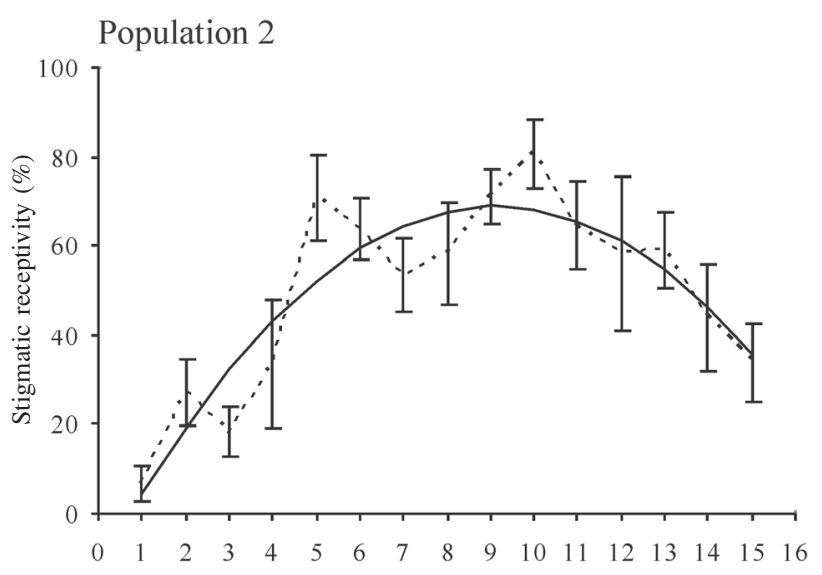

stigmatic receptivity $=-12.4221+17.7950 \mathrm{x} 0.9722 \mathrm{x}^{2}$ stigmatic receptivity $\max .=9.6481$ days

Population 3

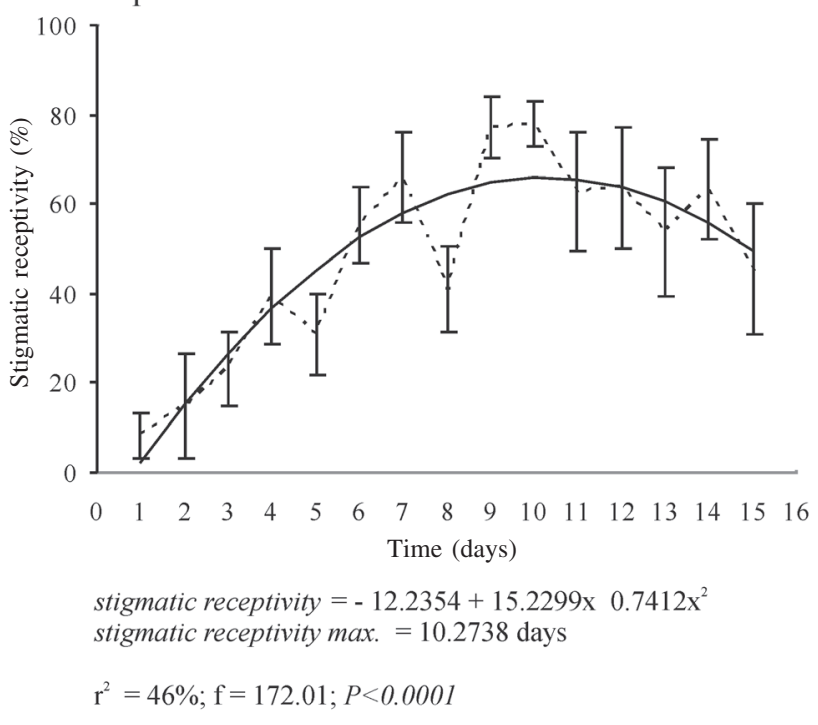

Figure 6. Trifolium polymorphum Poir. stigmatic receptivity. Observed average values (----) and second order polinomial model (-) for the three populations.
The aerial flowers of T. polymorphum do not show maximum functionality at anthesis onset. Aerial flowers reach maximum length at anthesis or three days later, as in population 1. Maximum flower width occurs two days after the beginning of anthesis; at the same time the vexilar petal is totally expanded. Maximum average values of pollen viability of $T$. polymorphum are reached one to two days after anthesis onset, which confirms that pollen does not necessarily attain functional maturity when anthers begin shedding pollen grains (Stone et al. 1995).

Maximum average values of stigmatic receptivity of $T$. polymorphum are reached three to four days after anthesis onset, and maximum pollen viability is reached one to two days after anthesis onset. Therefore, a functional gap occurs between pollen viability and the highest stigmatic receptivity, which does not coincide with the moment of anther dehiscence. Dichogamy is defined as the temporal separation of male and female functions (Bertin \& Newman 1993) and is interpreted as one of the evolutionary results that prevent self-pollination, avoiding inbreeding depression and increasing pollen dispersal efficiency by reducing antherstigma interference (Lloyd \& Webb 1986; Bertin \& Newman 1993; Sargent et al. 2006). In most published works (Langenberger \& Davis 2002; Bhardwaj \& Eckert 2001), dichogamy is detected by the visual registration of anther dehiscence and morphological changes at the stigma level (e.g., evident stigmatic secretions), and the functionality of male and female whorls is generally not numerically quantified. The quantitative evaluation of functionality in both whorls determines how both functions are temporarily separated. This is important information previous to manual pollinations in order to determine the breeding system of plant species. In the aerial flowers of T. polymorphum, stigmatic receptivity was detected previous to anthesis onset, and a high percentage of flowers showed anther dehiscence during pre-anthesis $(60 \%$ and $80 \%$ in populations 1 and 2 , respectively). This indicates that autonomous selfpollinations would be possible before anthesis (Lloyd \& Schoen 1992). Only the variation registered in the spatial arrangement of anthers and stigma, acting as a temporary herkogamy, establishes a mechanical barrier to selfpollination throughout flower development. The greatest separation between both whorls is recorded two days before anthesis, when the stigma surpasses anther height. Although certain stigmatic receptivity is recorded and some flowers show anther dehiscence, the distance between both whorls would prevent self-pollination in the flower bud. This distance shortens, the shortest being recorded a day after anthesis. This behavior of reproductive whorls and anther dehiscence before anthesis was also registered in Trigonella balansae (Trifolieae), which is a mixed breedingsystem species (Nair et al. 2004)

Flower longevity has been defined either as the length of time an individual flower remains open in the field with fresh-appearing perianth, stigma, and stamens (Primack 1985) or the period between anthesis onset and floral 


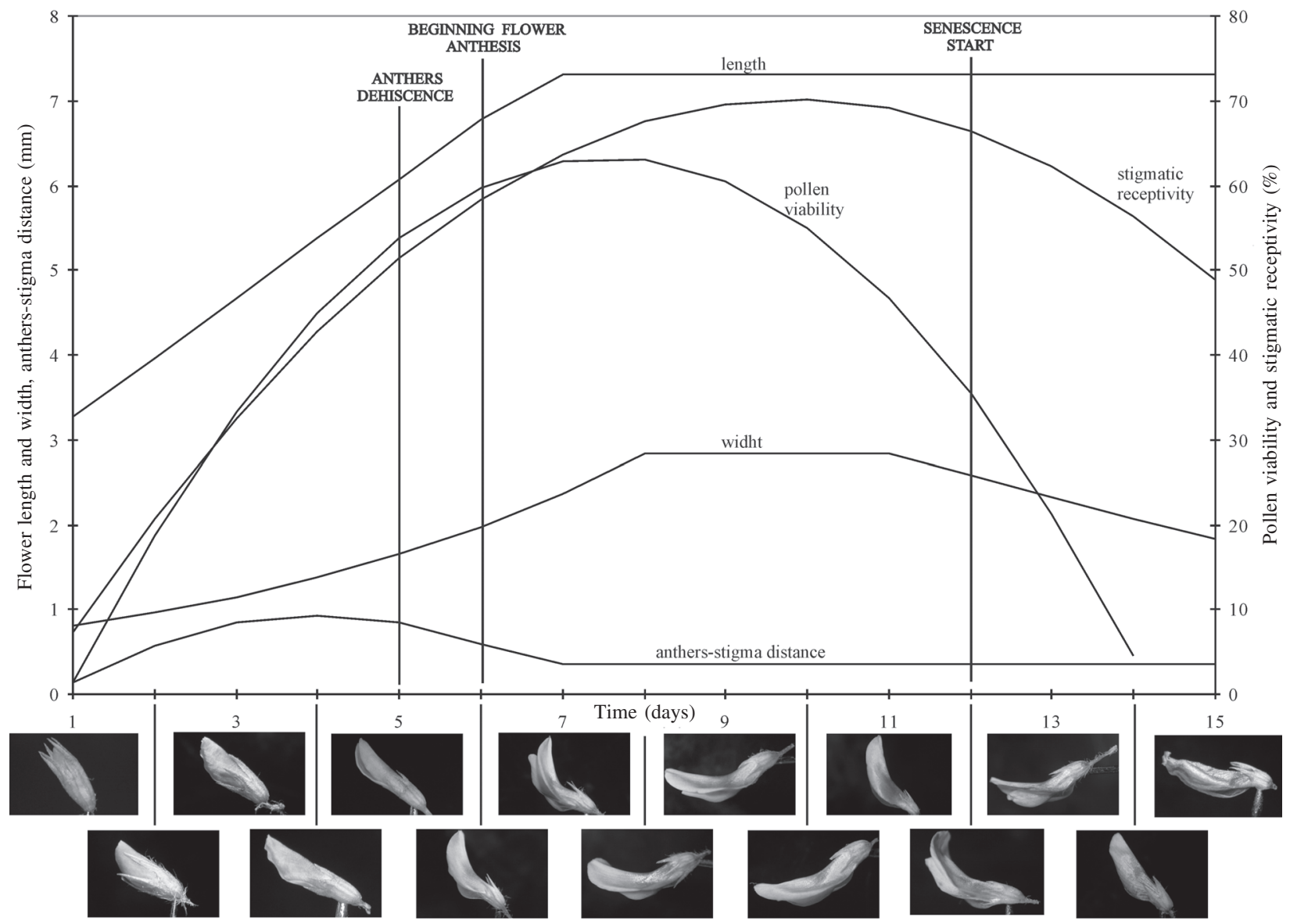

Figure 7. Estimated models in Trifolium polymorphum Poir. for all parameters: flower length and width, anthers-stigma distance (mm), pollen viability and stigmatic receptivity $(\%)$. Beginning flower anthesis, anthers dehiscence and senescence start are marked.

senescence (Ashman \& Schoen 1995). During such a period, flowers remain open and pollinators have greater activity, with consequent implications for outcrossing. This is a very important period in floral reproductive biology, as it implies high floral construction and maintenance costs for plants. Numerous works have related floral longevity to habitat, taxonomic component, pollination vector, flower sexuality (Primack 1985), breeding system (Primack 1985; Karle \& Boyle 1999), genetic component and external variables (Preston 1991) such as temperature, humidity and photoperiod (Scott et al. 1994). Empirical models related to floral development and maintenance costs have been developed (Ashman \& Schoen 1994; 1995; Schoen \& Ashman 1995; Charnov 1996). Flower longevity in T. polymorphum for the populations studied here lasted 5 to 6 days. This recorded period was obtained in cultivated experimental conditions (without environmental factor control) in which the pollination effect was not considered. Pollination usually reduces floral longevity by means of ethylene production (Stead 1992; Proctor \& Harder 1995; van Doorn 1997; Arathi et al. 2002), and it is a way to minimize the invested female resources and assure male fitness by reducing pollen-grain competition once the grains reach the stigmatic surface (Lankinen et al. 2006). It is likely to assume that some variation in flower longevity found in T. polymorphum could be explained by this cause.

Flower longevity is a very important period in angiosperm reproductive biology because of the interaction with potential pollinators. However, floral events that occur during pre-anthesis could affect or determine the breeding system of plants. In T. polymorphum, with underground cleistogamous flowers with obligate autogamy, anther dehiscence and stigmatic receptivity detected during pre-anthesis in a high percentage of aerial flowers may also be facilitating spontaneous autogamy in this type of flower. In addition, it is possible to point out that three aerial flowers showed pollen-tube growth extending through the indehiscent anther wall during pre-anthesis as was described for underground flowers of T. polymorphum (Speroni 2000; Speroni \& Izaguirre 2001) and other amphicarpic species (Uphof 1938). If aerial flowers are also allogamous and self-compatible as was proposed by Real et al. (2007), the possibility of cross-pollination during aerial flower anthesis (at the time pollen viability and stigmatic receptivity show the highest values) may represent an important incorporation of genetic variability in a species that combines autogamous underground flowers with vegetative propagation by stolons. 


\section{Acknowledgments}

This work is part of the PhD. thesis of the first author under Programa de Desarrollo en Ciencias Básicas (PEDECIBA), which is being developed at the Laboratorio de Botánica, Facultad de Agronomía, UDELAR. We thank PEDECIBA and the staff at the Laboratorio de Botánica, especially Ing. Agr. Daniel Bayce for field assistance. We thank the valuable help of the two anonymous assessors that, through their suggestions and corrections, helped us improve this article.

\section{References}

Arathi, H.S.; Rasch, S.; Cox, C. \& Kelly, J.K. 2002. Autogamy and floral longevity in Mimulus guttatus. International Journal of Plant Sciences 163: 567-573.

Ashman, T-L. \& Schoen, D.J. 1994. How long should flowers live? Nature 371: 788-790.

Ashman, T.-L. \& Schoen, D.J. 1995. Floral longevity: fitness consequences and resource costs. Pp. 112-139. In: D.G. Lloyd \& S.C.H. Barrett (eds.). Floral biology. Studies on floral evolution in animal-pollinated plants. New York, Chapman \& Hall.

Bhardwaj, M. \& Eckert, C.G. 2001. Functional analysis of synchronous dichogamy in flowering rush, Butomus umbellatus (Butomaceae). American Journal of Botany 88: 2204-2213.

Bertin, R.I. \& Newman, C.M. 1993. Dicogamy in Angiosperms. Botanical Review 59: 112-152.

Burkart, A. 1987. Flora Ilustrada de Entre Ríos. III. Colección Científica del INTA 6. Buenos Aires.

Charnov, E.L. 1996. Optimal flower lifetimes. Evolutionary Ecology 10: $245-248$.

Coll, J. \& Zarza, A. 1992. Leguminosas nativas promisorias: Trébol polimorfo y babosita. Boletín de Divulgación del Instituto Nacional de Investigaciones Agropecuarias 22: 1-18.

Dafni, A. 1992. Pollination ecology. A practical approach. New York, IRL Press at Oxford Univ. Press.

Draper, N. \& Smith, H. 1981. Applied regression analysis. $2^{\text {nd }}$ ed. New York, John Wiley \& Sons.

Izaguirre, P. 1995. Especies indígenas y subespontáneas del género Trifolium L. (Leguminosae) en el Uruguay. Boletín de Divulgación del Instituto Nacional de Investigaciones Agropecuarias 58: 1-22.

Karle, R. \& Boyle, T.H. 1999. Relationships between floral morphology, breeding behavior, and flower longevity in easter cactus. Journal of the American Society for Horticultural Science 124: 296-300.

Langenberger, M.W. \& Davis, A.R. 2002. Temporal changes in floral nectar production, reabsorption, and composition associated with dichogamy in annual caraway (Carum carvi; Apiaceae). American Journal of Botany 89: 1588-1598.

Lankinen, A.; Hellriegel, B. \& Bernasconi, G. 2006. Sexual conflict over floral receptivity. Evolution 60: 2454-2465.

Lloyd, D.G. \& Schoen, D.J. 1992. Self-and cross-fertilization in plants. I. Functional dimensions. International Journal of Plant Sciences 153: 358-369.
Lloyd, D.G. \& Webb, C.J. 1986. The avoidance of interference between the presentation of pollen and stigmas in angiosperms. New Zealand Journal of Botany 24: 135-162.

Nair, R.M.; Dundas, I.S.; Wallwork, M.; Verlin, D.C.; Waterhouse, L. \& Dowling, K. 2004. Breeding system in a population of Trigonella balansae (Leguminosae). Annals of Botany 94: 883-888.

Preston, R.E. 1991. The intrafloral phenology of Streptanthus tortuosus (Brassicaceae). American Journal of Botany 78: 1044-1053.

Primack, R.B. 1985. Longevity of individual flowers. Annual Review of Ecology and Systematics 16: 15-37

Proctor, H.C. \& Harder, L.D. 1995. Effect of pollination success on floral longevity in the orchid Calypso bulbosa (Orchidaceae). American Journal of Botany 82: 1131-1136.

Real, D.; Dalla Rizza, M.; Reyno, R. \& Quesenberry, K.H. 2007. Breeding system of the aerial flowers in an amphicarpic clover species: Trifolium polymorphum. Crop Science 47: 1401-1406.

Rossow, R.A. 1999. Trifolium L. Pp. 734-735. In: F.O. Zuloaga \& O. Morrone (eds.). Catálogo de las Plantas Vasculares de la República Argentina II. Fabaceae-Zygophyllaceae (Dicotyledoneae). St. Louis, Missouri Botanical Garden Press.

Sargent, R.D.; Mandegar, M.A. \& Otto, S.P. 2006. A model of the evolution of dichogamy incorporating sex-ratio selection, antherstigma interference, and inbreeding depression. Evolution 60: 934-944.

Schoen, D.J. \& Ashman, T.-L. 1995. The evolution of floral longevity: resource allocation to maintenance versus construction of repeated parts in modular organisms. Evolution 49: 131-139.

Scott, D.; Boyle, T.H. \& Han, S.S. 1994. Floral development and flower longevity in Rhipsalidopsis and Schlumbergera (Cactaceae). HortScience 29: 898-900.

Shivanna, K.R. \& Rangaswamy, N.S. 1992. Pollen biology. A laboratory manual. Berlin, Springer-Verlag.

Speroni, G. 2000. Aspectos de la biología reproductiva de Trifolium polymorphum Poir. (Fabaceae, Papilionoideae). Tesis de Maestría en Ciencias Biológicas. Opción Botánica. Programa de Desarrollo en Ciencias Básicas, Uruguay.

Speroni, G. \& Izaguirre, P. 2001. Morfología y esporogénesis en flores aéreas y subterráneas de la especie anficárpica Trifolium polymorphum (Fabaceae, Papilionoideae). Boletín de la Sociedad Argentina de Botánica 36: 253-265.

Speroni, G. \& Izaguirre, P. 2003. Características biológicas de la leguminosa nativa promisoria forrajera Trifolium polymorphum Poir. (Fabaceae, Faboideae). Agrociencia VII: 68-76.

Stead, A.D. 1992. Pollination-induced flower senescence: a review. Plant Growth Regulation 11: 13-20.

Stone, J.L.; Thomson, J.D. \& Dent-Acosta, A.J. 1995. Assessment of pollen viability in hand-pollination experiments: a review. American Journal of Botany 82: 1186-1197.

Uphof, J.C.Th. 1938. Cleistogamic flowers. Botanical Review 4: 21-49.

Van Doorn, W.G. 1997. Effect of pollination on floral attraction and longevity. Journal of Experimental Botany 48: 1615-1622. 